\title{
Psychological Problems of Parents in Learning Assistance During Covid-19 Pandemic
}

\author{
M. Ichsan Nawawi ${ }^{1}$, Rofia Masrifah ${ }^{2}$, Hikmawati Pathuddin ${ }^{3}$, Khaerun Nisa ${ }^{4}$, Khalilah \\ Nurfadilah $^{5}$, Muh. Irwan ${ }^{6}$ \\ \{ichsan.nawawi@uin-alauddin.ac.id ${ }^{1}$ \} \\ Mathematics Department, Universitas Islam Negeri Alauddin Makassar, 92111, Indonesia 1,2,3,5,6 \\ Research and Development Center, Kementrian Agama Makassar, 90232, Indonesia ${ }^{4}$
}

\begin{abstract}
Indonesian government issued a policy of e-learning system to replace offline learning during this global pandemic. Parents must be adaptable quickly, being companions or second teachers, although not all parents are prepared for this changing. The important to note is the ability to be mentors and the psychology of parents. The method used is the chi-square test with SPSS application. Respondents were 215 parents of students by a questionnaire instrument (G-form) at Sulawesi island in random sampling technique. By the results of this research in using the chi-square method, there is a relation between the readiness of parents in e-learning assistance with the psychological sides of parents, such as emotions, fatigue and stress in the case study of parents in Sulawesi island. This research can be improved by expanding the sample to all islands in Indonesia and also as an education for parents to provide the variety fun learning assistants for their children by the qualified psychological readiness.
\end{abstract}

Keywords: Online learning; psychological parents; chi-square

\section{Introduction}

The COVID-19 pandemic is an epidemic that is experienced for all countries in the world. Early March 2020, the President of Indonesia, Joko Widodo announced to all Indonesian people that the first confirmed cases of 2 Indonesians were positive for COVID-19. The COVID-19 pandemic has caused the economy in Indonesia to plummet. Not only has that, but the world of education also felt the impact of this pandemic [1].

Direct learning that has been felt in the world of education has turned into online learning. This was done to prevent the spread of Covid-19 in the school environment. On March 16, 2020, all schools in Indonesia implemented the online student learning method, known as the online learning system (online). Where in this case both teachers and students must prepare learning aids in the form of technology such as gadgets, laptops or computers [2].

The COVID-19 pandemic initiates a broad, sudden, and dramatic digital transformation in society [3]. The pandemic is forcing us to take a tremendous digital leap in children's primary education. This requires significant adjustments not only from children and their teachers, but also from their families. During the Covid-19 pandemic there is stress, emotional anxiety and even additional burdens for children, teachers and parents [4]. Public health researchers have raised concerns about the 2019 coronavirus disease (COVID-19) pandemic and further public 
health responses will increase interpersonal stress and even risk of suicide [5]. The COVID-19 pandemic is a significant mental health threat among children [6]. In online learning, there are many negative effects, one of which is stress, many parents have high levels of stress thinking about their children [7].

This research aims to determine the relationship between the readiness of parents to assist their children in online learning with the psychological experiences (additional burdens, emotions, fatigue and even stress). For this reason, the chi-square test is used as a method that helps to determine which psychological (additional burden, emotion, fatigue and even stress) has a significant effect.

\section{Method}

\subsection{Sample}

This survey study was conducted on the island of Sulawesi with several respondents who were parents of students from various levels of kindergarten-junior high school. Overall the number of respondents was 215 people. The survey was conducted using the help of google form which is a small step to prevent the Covid-19 pandemic. The majority of them were aged between 37 to 43 years $(39.53 \%)$, then those aged between 30 to 36 years $(31.63 \%)$, those aged between 44 to 50 years $(18.14 \%)$, a few were between 23 to 29 years $(6.51 \%)$, few between 51 to 57 years $(3.26 \%)$, very few between 16 to 22 years $(0.93 \%)$.

Their jobs are also very varied: self-employed, state / private employees, civil servants, others and not working. Most of them have 3 children $(38.60 \%)$, then they have 2 children $(31.16 \%)$, few have 1 child $(12.56 \%)$, few have 4 children $(11.16 \%)$ and very few who have more than 4 children $(6.51 \%)$.

\subsection{Questionnaire}

The questionnaire consists of three parts and includes 16 closed questions and one open question. Closed questions and rating scales provide a snapshot of parents' beliefs and attitudes about online learning. In contrast, open-ended questions allow parents to express their feelings, experiences, personal knowledge and suggestions regarding online learning.

Part I: Demographic information. This section has four questions. Table 1 is information about the sample regarding the age, occupation and number of children owned by the respondent.

Part II: Online learning during COVID-19. This section describes the status of children's online learning at home during the pandemic with 7 questions. Questions covered the experiences of parents as companions for children at home during the Covid-19 pandemic

Part III: This section discusses several forms of psychological disorders experienced by parents in accompanying children to learn online during the Covid-19 pandemic which includes 4 questions about whether online learning is a burden, parents who are often emotional if they do not fully understand the material in mentoring online learning, parents who sometimes feel tired and stressful. 
Table 1. Information on samples

\begin{tabular}{llc}
\hline \multicolumn{1}{c}{ Participants } & \multicolumn{1}{c}{ Groups } & $\mathbf{N}(\boldsymbol{\%})$ \\
\hline Ages & 16-22 years old & $2(0,93 \%)$ \\
& 23-29 years old & $14(6,51 \%)$ \\
& 30-36 years old & $68(31,63 \%)$ \\
& 37-43 years old & $85(39,53 \%)$ \\
& 44-50 years old & $39(18,14 \%)$ \\
& 51-57 years old & $7(3,26 \%)$ \\
\hline Occupations & Entrepreneur & $27(12,56 \%)$ \\
& Officers BUMN & $16(12,56 \%)$ \\
& PNS & $46(7,44 \%)$ \\
& Jobless & $69(32,09 \%)$ \\
& Others & $57(26,51)$ \\
\hline Number of children & 1 & $27(12,56 \%)$ \\
& 2 & $67(31,16 \%)$ \\
& 3 & $83(38,60 \%)$ \\
& 4 & $24(11,16 \%)$ \\
& $>4$ & $14(6,51)$ \\
\cline { 2 - 3 }
\end{tabular}

\section{Results and Discussion}

The method used in this research is chi-square. The chi-square test is a nonparametric test used to test the relationship or effect of two or more variables. This method analyzes categorical data. In this study, the aim of this research is to determine the relationship between the readiness of children's mentoring in online learning with: a. parents feel that they are an additional burden, b. parents become emotional, c. parents sometimes feel tired, d. make parents stress in terms of sharing time, understanding learning materials, cooperation with children, finances.

$\mathrm{H}_{0}$ : There is no association between readiness for mentoring and Psychological parents (additional burden, stress, tired, emotion)

$\mathrm{H}_{1}$ : There is an association between readiness for mentoring and Psychological parents (additional burden, stress, tired, emotion)

Then, association between readiness for mentoring and psychological parents (additional burden) is presented in Table 2 as follows.

Table 2. Association between readiness for mentoring and psychological parents

\begin{tabular}{|c|c|c|c|c|}
\hline \multirow{2}{*}{\multicolumn{2}{|c|}{ Actual Data }} & \multicolumn{2}{|c|}{ Psychological parents (additional burden) } & \multirow{2}{*}{ TOTAL } \\
\hline & & Yes & No & \\
\hline Readiness & Yes & 156 & 31 & 187 \\
\hline mentoring & No & 22 & 6 & 28 \\
\hline \multicolumn{2}{|c|}{ TOTAL } & 178 & 37 & 215 \\
\hline
\end{tabular}

Then, expected value association between readiness for mentoring and psychological parents (additional burden) is presented in Table 3 as follows. 
Table 3. Expected value association between readiness for mentoring and psychological parents

\begin{tabular}{lcccc}
\hline & & \multicolumn{2}{c}{ Psychological parents (additional burden) } \\
\cline { 3 - 5 } & \multirow{2}{*}{ Expected } & & Yes & No \\
\hline Readiness & \multirow{2}{*}{ for } & Yes & 154,82 & 32,18 \\
mentoring & & No & 23,18 & 4,82 \\
\hline
\end{tabular}

$\chi^{2}=0,402$

We fail to reject the null hypothesis or in other words we accept our null hypothesis and conclude that there is no association between readiness for mentoring and psychological parents (additional burden): 2, 70. 100\% online learning makes parents support, facilitate and report children's progress to the teacher. Parents don't assistance their children in online learning is an additional burden [8]. Then, association between readiness for mentoring and psychological parents (stress) is presented in Table 4 as follows.

Table 4. Association between readiness for mentoring and psychological parents (stress)

\begin{tabular}{|c|c|c|c|c|}
\hline \multirow{2}{*}{\multicolumn{2}{|c|}{ Actual Data }} & \multicolumn{2}{|c|}{ Psychological parents (stress) } & \multirow{3}{*}{$\begin{array}{c}\text { TOTAL } \\
187\end{array}$} \\
\hline & & Yes & No & \\
\hline \multirow{2}{*}{$\begin{array}{ll}\begin{array}{l}\text { Readiness } \\
\text { mentoring }\end{array} & \text { for } \\
\end{array}$} & Yes & 128 & 59 & \\
\hline & No & 24 & 4 & 28 \\
\hline \multicolumn{2}{|l|}{ TOTAL } & 152 & 63 & 215 \\
\hline
\end{tabular}

The COVID-19 pandemic has caused significant stress and emotions for many parents around the world [9]. Then, expected value association between readiness for mentoring and psychological parents (stress) is presented in Table 5 as follows.

Table 5. Expected value association between readiness for mentoring and psychological parents (stress).

\begin{tabular}{lllcc}
\hline \multicolumn{2}{c}{ Expected } & & \multicolumn{2}{c}{ Psychological parents (stress) } \\
\cline { 3 - 5 } & & Yes & No \\
\hline Readiness & for & Yes & 132,20 & 54,79 \\
mentoring & & No & 19,79 & 8,20 \\
\hline
\end{tabular}

$$
\chi^{2}=3,504
$$

We reject the null hypothesis or in other words we accept our null hypothesis and conclude that there is an association between readiness for mentoring and psychological parents (stress). Parents of school-age children have felt the drastic changing due the COVID-19 pandemic that caused the moderate stress level [10]. Then, association between readiness for mentoring and psychological parents (tired) is presented in Table 6 as follows.

Table 6. Association between readiness for mentoring and psychological parents (tired).

\begin{tabular}{ccccc}
\hline \multirow{2}{*}{ Actual Data } & & \multicolumn{2}{c}{ Psychological parents (tired) } & \multirow{2}{*}{ TOTAL } \\
\cline { 3 - 4 } & & Yes & Yes & \\
\hline Readiness for & Yes & 128 & 24 & 152 \\
mentoring & No & 59 & 4 & 63 \\
\hline TOTAL & & 187 & 28 & 215 \\
\hline
\end{tabular}


Then, expected value association between readiness for mentoring and psychological parents (tired) is presented in Table 7 as follows.

Table 7. Expected value association between readiness for mentoring and psychological parents (tired).

\begin{tabular}{clcc}
\hline \multirow{2}{*}{ Expected } & & \multicolumn{2}{c}{ Psychological parents (tired) } \\
\cline { 3 - 4 } & & Yes & No \\
\hline Readiness for & Yes & 132,20 & 19,79 \\
mentoring & No & 54,79 & 8,20 \\
\hline
\end{tabular}

$$
\chi^{2}=3,504
$$

We reject the null hypothesis or in other words we accept our null hypothesis and conclude that there is an association between readiness for mentoring and psychological parents (tired). Then, association between readiness for mentoring and psychological parents (emotion) is presented in Table 8 as follows.

Table 8. Association between readiness for mentoring and psychological parents (emotion).

\begin{tabular}{ccccc}
\hline \multirow{2}{*}{ Actual Data } & & \multicolumn{2}{c}{ Psychological parents (emotion) } & \multirow{2}{*}{ TOTAL } \\
\cline { 2 - 4 } & & Yes & No & \\
\hline Readiness for & Yes & 103 & 84 & 187 \\
mentoring & No & 22 & 6 & 28 \\
\hline TOTAL & & 125 & 90 & 215 \\
\hline
\end{tabular}

The COVID-19 crisis has contributed to the increase overcome the emotional of parents [11]. Then, expected value association between readiness for mentoring and psychological parents (tired) is presented in Table 9 as follows.

Table 9. Expected value association between readiness for mentoring and psychological parents (tired).

\begin{tabular}{cccc}
\hline \multicolumn{2}{c}{ Expected } & & \multicolumn{2}{c}{ Psychological parents (emotion) } \\
\cline { 3 - 4 } & & Yes & Yes \\
\hline \multirow{2}{*}{$\begin{array}{c}\text { Readiness for } \\
\text { mentoring }\end{array}$} & Yes & 108,72 & 78,28 \\
\cline { 2 - 4 } & No & 16,28 & 11,72 \\
\hline
\end{tabular}

$$
\chi^{2}=5,520
$$

We reject the null hypothesis or in other words we accept our null hypothesis and conclude that there is an association between readiness for mentoring and psychological parents (emotion).

\section{Conclusion}

Online learning has become increasingly popular since the Covid 19 pandemic to continue our education system. Parents also have to adjust quickly to solve online learning problems. Among the many advantages, online learning also has a negative impact, from the results of 
research conducted on the island of Sulawesi with 215 parents as respondents, it turns out that there is an association between readiness for mentoring and psychological parents (stress, tired, emotion) except additional burden. the feeling of emotion that is felt by students is also transmitted to their parents also increased stress and extremely tired on parents.

\section{References}

[1] WHO, “Coronavirus Disease 2019 (COVID-19) World Health Situation Report - 1," WHO Indones. Situat. Rep., vol. 2019, no. March, pp. 1-6, 2020

[2] A. Abidah, H. N. Hidaayatullaah, R. M. Simamora, D. Fehabutar, and L. Mutakinati, "The Impact of Covid-19 to Indonesian Education and Its Relation to the Philosophy of 'Merdeka Belajar,"' Stud. Philos. Sci. Educ., vol. 1, no. 1, pp. 38-49, 2020, doi: 10.46627/sipose.v1i1.9.

[3] N. Iivari, S. Sharma, and L. Ventä-Olkkonen, "Digital transformation of everyday life - How COVID19 pandemic transformed the basic education of the young generation and why information management research should care?,” Int. J. Inf. Manage., vol. 55, no. June, p. 102183, 2020, doi: 10.1016/j.ijinfomgt.2020.102183.

[4] B. M. Smith, A. J. Twohy, and G. S. Smith, "Psychological inflexibility and intolerance of uncertainty moderate the relationship between social isolation and mental health outcomes during COVID-19," J. Context. Behav. Sci., vol. 18, no. September, pp. 162-174, 2020, doi: 10.1016/j.jcbs.2020.09.005.Latief, H., As'ad, S., Khasanah, M. 2015. Fleksibilitas Pemaknaan Wakaf Tunai di Indonesia: Studi terhadap Lembaga Filantropi dan Lembaga Keuangan. Jurnal Afkaruna, Vol. 11 Nomor 1, Juni 2015

[5] D. Crasta, J. S. Daks, and R. D. Rogge, "Modeling suicide risk among parents during the COVID-19 pandemic: Psychological inflexibility exacerbates the impact of COVID-19 stressors on interpersonal risk factors for suicide," J. Context. Behav. Sci., vol. 18, no. September, pp. 117-127, 2020, doi: 10.1016/j.jcbs.2020.09.003

[6] S. Yeasmin et al., "Impact of COVID-19 pandemic on the mental health of children in Bangladesh: A cross-sectional study," Child. Youth Serv. Rev., vol. 117, no. July, p. 105277, 2020, doi: 10.1016/j.childyouth.2020.105277.

[7] M. Brown, J. R. Doom, S. Lechuga-Peña, S. E. Watamura, and T. Koppels, "Stress and parenting during the global COVID-19 pandemic," Child Abus. Negl., no. August, 2020, doi: 10.1016/j.chiabu.2020.104699.

[8] S. Smith, P. Burdette, G. Cheatham, and S. Harvey, "Parental Role and Support for Online Learning of Students with Disabilities: A Paradigm Shift.," J. Spec. Educ. Leadersh., vol. 29, no. 2, pp. 101112, 2016, [Online]. Available: https://files.eric.ed.gov/fulltext/EJ1118423.pdf

[9] L. W. Coyne, E. R. Gould, M. Grimaldi, K. G. Wilson, G. Baffuto, and A. Biglan, "First Things First: Parent Psychological Flexibility and Self-Compassion During COVID-19," Behav. Anal. Pract., 2020, doi: 10.1007/s40617-020-00435-w.

[10] E. Susilowati, P. Kesejahteraan, S. Bandung, M. Azzasyofia, S. Tinggi, and K. Sosial, "The Parents Stress Level in Facing Children Study From Home in the Early of The Parents Stress Level in Facing Children Study From Home in the Early of Covid-19 Pandemic in Indonesia," no. July, 2020, doi: 10.200609/ijsoc.v2i3.117.

[11] D. Marchetti, L. Fontanesi, C. Mazza, S. Di Giandomenico, P. Roma, and M. C. Verrocchio, "Parenting-related exhaustion during the italian COVID-19 lockdown," J. Pediatr. Psychol., vol. 45, no. 10, pp. 1114-1123, 2020, doi: 10.1093/jpepsy/jsaa093. 